VIJAY PEREIRA, SURENDER MUNJAL AND M.K. NANDAKUMAR

\title{
Reverse Dependency
}

A Longitudinal Case Study Investigation into Headquarter-Subsidiary Relationship in the Context of an Emerging Economy

Abstract: This study provides a conceptual framework and typology to measure headquarter and subsidiary dependency on capabilities and resources. Using an in-depth longitudinal case study approach, it highlights a novel phenomenon called 'reverse dependency' where headquarters dependency on its subsidiary is rising. This is an emerging phenomenon, probably related to increased globalization and convergence of the world economy. The study offers implications for theory of subsidiary entrepreneurship and location embeddedness. .

Vijay Pereira is a Senior Lecturer in International and Strategic HRM, Department of Organizational Studies and HRM, University of Portsmouth, Portsmouth Business School, Richmond Building, Portland Street, PO1 3DE Portsmouth, United Kingdom, telephone- +44 (0)239284 44815 email-Vijay.Pereira@ @ort.ac.uk; Surender Munjal is a Lecturer in

International Business, Centre for International Business, Leeds University Business School

(CIBUL), University of Leeds, James E. Lynch India and South Asia Business Centre, 12-14

Cromer Terrace, LS2 9JT, United Kingdom, telephone: +44 (0) 113343 8080, email-

smu@ lubs. leeds.ac.uk; M.K. Nandakumar is an Associate Professor (Strategic Management) at

570, Kerala, India, Tel: +91-495-2809256, Email: mknkumar@ hotmail.com 
In the context of the changing power balance between $\mathrm{HQ}$ and subsidiary, this study examines HQ dependence on its subsidiaries in the context of the location where the subsidiary is embedded. We argue that when the subsidiary is based in an emerging economy, such as India, where the strategic assets and institutions are evolving, HQ benefits immensely from the knowledge transfer, strategic resources and competencies of the subsidiary (see for e.g. Ramamurthy 2012). It is in this context that we envisage that HQ's becomes dependent on its subsidiary.

In this study we provide a theoretical framework that offers a typology of HQ-subsidiary dependence and allows for mapping of different degrees of dependence. Moreover, we extend the literature on HQ-subsidiary relationship by delineating the circumstances under which the subsidiary gains a degree of importance and control, such that the HQ then tends to depend on the subsidiary. Mudambi, Pedersen and Andersson (2014) have recently explained how a subsidiary gains power in multinational corporations. Taking that argument further this study proposes the consequence of such an eventuality i.e., where a subsidiary gains importance and control within a MNE, and the HQ may become dependent on the subsidiary.

Largely, this study has implications for resource dependence theory and suggestions for managers of MNEs. This study also takes a closer look at the processes and drivers that provide power to the subsidiary within the MNE. There is a gap in the literature in its analysis of the processes and drivers of subsidiary evolution and this study aims to close this gap by providing empirical evidence through an in-depth examination of a longitudinal case study, involving a subsidiary of a foreign MNE in India. A case study enables us to provide findings that can be easily understood by managers in MNEs. 


\section{Literature review}

An organization that controls and manages subsidiaries located in, at least, two countries can be termed as an MNE (Teece 1985). Headquarters implement different types of managerial activities, transfer knowledge and resources to its subsidiaries, and create an appropriate structure within the organization. The aim of HQ is to create a network, as has been described by Williamson's (1981) in his transaction cost economics (TCE) theory. Thus TCE suggests maximization of MNE performance through the reduction of transaction costs. Thus, for example, the very basis of the offshore outsourcing phenomenon is cost saving, as the literature explains and suggests through the TCE theory (Williamson, 1981). This brings into perspective a strong focus on HQ network role (Dellestrand 2011)

The extant literature in international business and strategy identifies different models of HQ-subsidiary relationships. The traditional centralization based models suggests that HQ is a pool of knowledge and resources of the MNE (for details see Ghoshal and Nohria 1989). It is traditionally suggested that the competitive advantages of the MNE are directly related to the knowledge, resources and capabilities that should remain centralized, preserved and controlled by the MNE's HQ (Bates and Flynn 1995).

Fladmoe-Lindquist and Tallman (2002) suggest that HQ usually follows capability recognition strategies. HQ recognizes the subsidiary's current capabilities and distributes knowledge and resources on a need to know basis. Thus, HQ controls the amount of knowledge and resources that gets transferred to its subsidiary. However, such models seem to be inadequate to represent MNE's activities due to an increase in the globalization and internationalization of businesses, especially the involvement of emerging economy's subsidiaries. Subsidiaries that become 
centers for excellence (Holm and Pedersen 2000) tend to influence different functional areas of the MNE and actively shape its strategies (Bartlett and Ghoshal 1989; Birkinshaw, Hood, and Jonsson 1998).

Costello and Costello (2009) have developed a theoretical framework that explains the nature and design of HQ-subsidiary governance relationships. This framework is useful in examining the 'types of bundles' of governance mechanisms, which are used for better alignment of subsidiaries with headquarters, and the reasons why these governance mechanism are adopted by a particular multinational enterprise. Their studies suggest that three types of subsidiary bundles of governance are used by MNEs, namely, those that respectively depend on parentcentered governance mechanisms, subsidiary-centered governance mechanisms, and parent- and subsidiary- centered governance mechanisms. Costello and Costello (2009) also posit that the MNE's international strategy, its subsidiary's importance, environmental uncertainty faced by its subsidiary and the subsidiary's age are helpful in predicting the 'type of bundle' they use to align the interests of headquarters with a subsidiary.

Nohria and Ghoshal (1994) have examined two different approaches, namely 'differentiated fit' and 'shared values', for managing the relations between HQ and subsidiary in MNEs. The 'differentiated fit' approach is based on contingency theory and necessitates an understanding of specific control problems presented by the context of each subsidiary. It suggests that the MNE should make use of the right combination of formal structural elements to manage these contingencies.

In the decision-making process, conflicts between HQ and subsidiary occur. Conflict, in its dysfunctional form is conceptualized to be unhealthy and associated with negative outcomes, 
e.g. distortion and withholding of information to the detriment of others within the organization, and hostility and distrust during interactions (Thomas 1990). It is also argued that dysfunctional conflict is associated with opportunistic behavior (Barclay 1991), information gatekeeping (Jaworski and Kohli 1993), and the creation of obstacles to decision-making. In contrast, functional conflict is believed to have beneficial effects that flow from the consultative interactions that occur when functional conflict is present (Schwenk 1989). Under these circumstances, people feel free to express their opinions, and to challenge others' ideas, beliefs, and assumptions. Thus, a functional conflict positively affects the organization's performance whilst a dysfunctional conflict negatively affects its performance. Perceptions of both academics and managers regarding inter-organizational conflicts between $\mathrm{HQ}$ and their foreign subsidiaries in MNE have undergone a transformation, and, as a consequence, these conflicts are no longer viewed as dysfunctional, but a natural consequence of globalization (Schotter and Beamish 2011).

The 'shared values' approach could facilitate the creation of a common set of values and goals and minimize the divergent interests among the actors. Such an approach could also create a feeling of mutual interdependence. This idea confers to the resource dependence theory (Salancik and Pfeffer 1977), which, in the context of a MNE, states that (sub) units in an organization depend on other (sub) units to stabilize the flow of resources.

MNEs allow flow of knowledge and resources within various subsidiaries that enhances "smooth global operations, gain more market power, and achieve faster market entry" (Xia 2011, 229). The role of human resources in the flow of knowledge and skills among subsidiaries is particularly noted in the literature. Further, HQ orchestrates the flow of resources and skills between subsidiaries (Dellestrand 2011). However, in certain circumstances, such as when the 
pressure of global integration is low and local responsiveness is high, HQ's mandate for subsidiaries is to localize (Bartlett and Ghoshal 1989). It is in these situations that subsidiary entrepreneurship and autonomy emerge.

Localizing the subsidiary embedded within host location seeks to accesses foreign technology, skills and local market knowledge, that are location bound, in order to carry on its operations successfully (Bartlett and Ghoshal 1989). In localization strategy, HQ tends to preserve the subsidiary's autonomy because the subsidiary does not draw upon the HQ's central reserve of knowledge and resource. Thus, in such situations, both subsidiary and HQ have low dependence on each other.

Insert Figure 1 about here

Figure 1 below depicts our conceptual model and maps the existing literature on HQsubsidiary dependence. We call Cell 1.1 'preservation' as it exhibits the scenario when both HQ and subsidiary act independently, preserving their autonomy. Preservation strategy closely refers to Bartlett and Ghoshal's (1989) multi-domestic (or localization) strategies in the integrative responsiveness model. This type of strategy is particularly relevant when the pressure for localization is high and pressure for standardization is low. The MNE's subsidiary focuses on adaptation to the local market and HQ interference is kept low. An excellent example of where preservation is utilized as a strategy is Unilever. Different subsidiaries of Unilever across the world preserve their autonomy in almost every functional area of management.

Cell 3.1 is called 'dependence' as this presents the traditional case of HQ centered strategy, where the subsidiary is dependent upon HQ. This refers back to Ghoshal and Nohria (1989) type of centralization based governance model of MNE, where resources and capabilities 
are controlled by HQ. This type of strategy is more applicable to MNEs that deal with standardized products, such as electronic equipment's. In such cases, the subsidiary only performs the mandate given by HQ and remains dependent on $\mathrm{HQ}$

The traditional or conventional view of knowledge transfer suggests that knowledge transfer is likely to be either "transplantation" or "supplantation" (Mudambi 2002). When an MNE's primary objective was to exploit local markets, it would infuse knowledge from HQ to either transplant a degree of its own knowledge or to supplant the subsidiary's existing knowledge. Transplantation is essentially represented in cell 3.1 of our model. However, supplantation represents cell 2.2 , where the subsidiary supplements its own existing knowledge and resources to the ones transferred by the HQ. Gupta and Govindarajan (2000) suggest that subsidiaries may be motivated to transfer knowledge to their HQ as it could strengthen their strategic position in the organization. However, HQ would only be interested in transfers when it deems it to be beneficial from its point of view.

Cell 2.2 is, thus, called 'best of both'; as it portrays that in certain scenarios HQ and subsidiary can mutually exploit the capabilities and resources of each other. Fladmoe-Lindquist and Tallman (2002) referred to such a scenario as a 'capability driven' strategy. It means HQ and subsidiary builds protect and mutually exploit their capabilities. For instance, the network of the subsidiary can further leverage the internationalization of the MNE and gain access to resources not otherwise accessible to HQ. Thus, subsidiary and its network resources not only provide competitive advantage to the MNE but also become a basis for their mutual existence.

Moreover, reverse knowledge transfer can be beneficial to HQ in terms of accessing local knowledge, coordinating a global strategy, improving processes in the MNE's network, and 
providing new products. Another way for looking at this HQ-subsidiary relationship of knowledge transfer can be through what Cantwell and Mudambi (2005) term competence creation versus competence exploitation. On the one hand, HQs expect competence-creating subsidiaries to introduce new, unique and valuable knowledge that can be used by other corporate units and, for example, become centers of excellence (Holm and Pedersen 2000). On the other hand, competence-exploiting subsidiaries are expected to transfer and adapt knowledge from their HQ to local markets.

Yang, Mudambi and Meyer (2008) looked at leveraging knowledge from 'geographically disparate' subsidiaries. They found that knowledge transfers to and from geographically dispersed subsidiaries were a crucial source of competitive advantage for MNEs. Findings in the study also revealed that organizational characteristics are important in conventional knowledge flows from headquarters, so that subsidiaries, acquired with competence-creating objectives, receive significantly larger inflows. They concluded that knowledge characteristics are important in reverse flows to headquarters, so that subsidiaries whose knowledge is more relevant to HQs are able to transmit significantly larger outflows.

A recent article by Mudambi, Pedersen and Andersson (2013) focused on how power is gained in MNEs and their subsidiaries. More specifically, they looked at the intra-organizational network of MNEs, drawing on the resource dependence literature. They found that mutual dependence and dependence imbalance provide strong explanations for the subsidiary's power. Findings from their study also suggested that subsidiary power over strategic decisions in the MNE is gained through functional power. This is more in terms of the possession of technological, rather than business-related power. Further, there was reinforcement between 
technological and business related powers, as they both were strengthening the subsidiary's strategic power in the MNE network.

Through our conceptual model presented in Figure 1, we have portrayed a novel scenario where the subsidiary tends to gain greater power. In such a situation HQ becomes more dependent on the subsidiary. This situation, shown in Cell 1.3, is converse to the traditional centralization based models of HQ-subsidiary relationship and, hence, we term it as 'reverse dependency'. This is a step further to the scenario on HQ-subsidiary mutual dependencies depicted in cell 2.2, because in such a situation $\mathrm{HQ}$ is dependent on its subsidiary, rather than having a balanced and mutual exploitation of knowledge, strategic resources and capabilities.

We further argue that the 'reverse dependency' scenario is an emerging phenomenon. A greater number of such cases (where there is higher HQ dependency on subsidiary than the other way around) are surfacing, due to increased globalization of the world economy. When the subsidiary's entrepreneurship and other capabilities, knowledge, skills and resources rise to a significant level then it tends to substantially contribute and add greater value in terms of its overall position held in the MNE. For example, greater competencies, lower costs, skills, strategic positioning, client and customer satisfaction levels, and proven new business models are the seven a priori themes that emerge from the literature. Thus, when the subsidiary's share in the overall performance of the MNE reaches a certain point, HQ would naturally tend to be more dependent on the subsidiary's resources.

Mahlendorf, Rehrign, Schaffer and Wyszomirski, (2012) have concluded that the criteria, established by HQ to measure performance of subsidiary, tend to influence the decision-making of the subsidiary. However, once these performance criteria are overachieved by the subsidiary, 
the process may reverse itself and HQ decision-making may tend to be influenced by the subsidiary. The phenomenon of 'reverse dependency' is also associated with the location where the subsidiary is embedded. If the location of the subsidiary has unique immobile advantages (Dunning 1994) then such reverse dependency would arise. Thus, the locational context is particularly important. This phenomenon is being described here using a case study about a foreign MNE and its subsidiaries in India.

We name cell 3.3 in the top right corner of the theoretical framework in Figure

1 'transformation'. It shows a situation when HQ and the subsidiary dependency upon each other is high and mutual. This is a higher level of mutual dependence as compared to cell 2.2. It is also posited that the higher order dependence is not one sided as are the cases in cells 1.3 or 3.1. This fact demonstrates that the resources of $\mathrm{HQ}$ and subsidiary are mutually exploited by each other to a high degree. This can be associated with an efficient and effective utilization of resources that warrants high interactions and knowledge and resource flow between HQ and subsidiary. We envisage that if such high order dependence is followed it can bring in organizational and performance transformation in the MNE. Having discussed the relevant literature and forming a theoretical framework, we now move to the methodology section below.

\section{Methodology}

In order to investigate the phenomenon of HQ-subsidiary relationship in the context of knowledge and resource transfer, we adopt a longitudinal case study approach. The case study component of the research design is grounded in the approach set out by Yin (2009). A case study is defined as "an empirical inquiry that ... investigates a contemporary phenomenon in depth and within its real-life context when...the boundaries between phenomenon and context 
are not clearly evident" (Yin 2009, 18). We use the case study approach as a lot of information can be collected through a thorough analysis of a few cases. We have selected and portrayed a case study about a rural BPO, where an HQ from the advanced economy of the USA becomes dependent on entrepreneurial capabilities of the subsidiary in an emerging economy, namely, India.

We have used a single in-depth case study because of several reasons. First, in-depth case studies are regarded as a better approach when triangulation occurs within data or theories (Snow and Anderson 1991). Second, scholars, such as Welch, Piekkari, Plakoyiannaki and PaavilainenMäntymäki (2010), advocates the use of qualitative case studies in theorizing novel phenomena, such as HQ-subsidiary knowledge sharing strategies, as investigated in this study. Finally, scholars, such as Birkinshaw, Brannen and Tung $(2011,573)$, suggest that in order to understand "the complexities of emergent and evolving phenomena," such as in this study, it is often inappropriate to engage in large-scale, cross-sectional studies or reductionist methods in the absence of well-developed theory. Hence, thick description, exploratory research and comparative case analysis, that focus on inductive theory building and hypotheses generation, is more suitable in the context of this research. Another strength of this research is its longitudinal nature, as it was conducted over a two year period. Longitudinal studies within organizations are relatively rare (Pettigrew 1990, 284), being 'time and resource intensive'.

Interview data were recorded (with permission) and extensive summaries were produced from the recordings. A total of 12 interviews were carried out in two locations in the focal organization, over the two year research period of 2010-2012. The two locations for the study were Bangalore and Suratkal in South India. Interviews were conducted face-to-face and were tape-recorded and data were transcribed as is normally done. The senior managers that were 
interviewed included 2 directors, 1 general manager and 3 senior line managers. Six of the interviews were conducted in 2010-2011 and the other 6 in 2011-2012.

The analysis process here started with detailed writing up of what Pettigrew (1990) calls 'case history' for analysis within longitudinal research. Hence, within-case analysis typically involved detailed case study write-ups for each of the cases. These write-ups were often simply pure descriptions, but they were central to the generation of insight. Simultaneously, data were also analyzed using King's (2012) 'template analyses'. He explains that although this is an inductive process, in reality, a researcher will have some ideas as a result of research questions and the literature, and, therefore, it is possible to project what a priori themes may occur, and then work from a bottom up approach (refer to list of seven a priori themes identified in the literature review). Thus, 'themes are recurrent and distinctive features of participants' accounts, characterizing particular perceptions and/or experiences, which the researcher see as relevant to the research question" (King and Horrocks 2012, 150).

The authors were aware that this method may result in developing themes being overlooked without conscious analysis, and that they needed to be flexible in order to adapt the themes if they were not the most ideal method of depicting the data. The template is a process that can be modified continually through iterative analysis, and this template was followed here. King (2012) explains that template analysis is hierarchical in nature but unlike other types of thematic analysis the number of themes is not stipulated by the method of analysis but rather is developed through the process of analysis of the data for both the themes and sub-themes, otherwise referred to as "nested codes." 


\section{Case description}

'Rural BPO MNE' (hereinafter RBPO) is a US owned and headquartered niche human resource offshoring (HRO), part of the larger business process offshoring, i.e. BPO, and a services provider focused on mid-market companies. They support human resource (HR) processes across the entire employee life cycle spanning what they call 'hire to retire'. The BPO firm's unique vision for its Indian model is "to position rural talent to deliver leading IT solutions to global business by leveraging strengths of rural India supported by best practices established by the growing IT industry" (RBPO firm's website). Two of their operations in India are featured in this research: first, their 'center of excellence' in Bangalore, and, second, their 'rural' BPO (RBPO) operations in Suratkal in South India.

'RBPO' provides its clients with the opportunity to examine HR in a different BPO form. As the BPO industry has flourished in India, so more and more companies began establishing operations in the metropolitan cities to capitalize on the available human resources and physical infrastructure. However, this led to intense competition for available talent and frequent poaching of staff. Also, many employees considered a BPO job as a short-term one and opted for higher education or business management studies once they had earned enough money to support their higher education plans. These factors resulted in high employee turnover and attrition rates and, in turn, increased recruitment and training costs for many BPO companies (Budhwar and Bhatnagar 2009). There are two low cost solutions to this problem (NASSCOM 2010): the first is to Shift operations or a part of the operations to potential low cost areas, such as China, Malaysia, Philippines. The second solution is to tap the vast pool of skilled and cheap work force in rural areas in India itself. A number of Indian BPO organizations have chosen the first option, 
locating some businesses in China, Hong Kong and Singapore, as an alternative business location. A few BPO companies, including RBPO, took up the second option and have set up operations in smaller towns and villages. The low cost of operations and lower employee attrition levels are the key benefits that these companies derive from their rural operations. In contrast to the standard BPO industry, this case provides an opportunity to compare this organization's subsidiary entrepreneurial initiatives of operating in a rural location, with the BPO firm's Bangalore head-office becoming, over time, its country specific HQ (Budhwar 2012).

\section{Findings}

Seven major a priori themes emerged and were confirmed by data obtained from the respondents of the subsidiary dominating the case study organization. These were competition, costs, skills, strategic position to control employee attrition, control, client interface and satisfaction, and proven success of business models due to institutional contexts. These are first defined and then are illustrated by evidence taken from the case.

Competition is defined as the process of trying to win or do better than other external and internal competitors. Faced with competition and a threat to its current and future existence, the subsidiaries found ways of getting into competitive advantageous positions by exploiting the human resource in rural areas in India. As discussed above, the organization was faced with both global and local competition and the Indian subsidiary of the US HQ had two options. First, to allow HQ to shift operations or parts of their operations to potentially lower cost countries, and second, to tap and exploit the vast pool of skilled and cheap work force in rural areas in India itself, as described in the following statement: 
... I also wanted to test a new kind of a model that would prove that rural talent in India can deliver to departments of Global clients...so I started with this experiment on a very small scale...It's now almost two and a half years. We will be stepping into the third year. So that's the model we are working on...it is still evolving (Founder Member, Interview, Bangalore, 2010).

Cost is defined as a process of calculating and lowering the price or expense of producing goods and/or services in comparison to the competition and previous costs. Thus, an ability to deliver goods and services at lower costs put the subsidiaries in an advantageous position. |With

increasing costs, over time, the largely metropolitan locations of the operations at the subsidiary were beginning to get very costly, as explained by the following quote:

... if you look at our rural models, which consists of our largest group of entry level employees, they are typically falling into a salary range used by any other big $M N C$.... probably we are almost at the same level. We pay around one lakh eighty thousand rupees [a hundred and eighty thousand rupees per annum (approximately 2900 dollars per annum)] or something like that. But if we look at a three or four-year period probably our Tier 2, Tier 3 salaries would be about $40 \%$ less than what an associate would earn in a big MNC company (Board Member, Interview, Suratkal, 2011).

Skills are defined as the ability to do something well, usually gained through training or experience so as to result in competitive advantage. In this context the subsidiaries built upon their existing skills and strived to improve their skills bases. Even though technology is important, the BPO industry is extremely people oriented and centered, and, hence, the reliance on people's technical, soft and business management skills are extremely important. Both 
competition and cost are, thus, directly affected by the lack of quality and quantity of such skills, which was brought out over time through our longitudinal data. The following quote explains it:

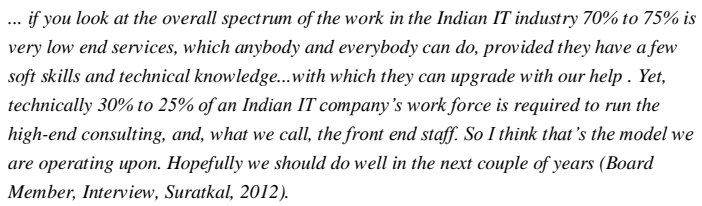

It is definitely a problem. Attrition is a big issue. The reason being is if the market picks up, so the demand for quality professionals and experience is always rated highly in the

IT sector. So attrition is an issue for any company that is in the mid segment, which is 
from 100 to 400 employees. But there are ways and means to try and reduce attrition through various processes, strategies and policies. Our attrition rates last year were about $20 \%$. This year it's gone up to $25 \%$, but, again, this year we are planning to bring it down to about $15 \%$ to $18 \%$, and slowly reduce it to about $10 \%$. We, as the center of excellence, are better and more strategically positioned as compared to our $\mathrm{HQ}$ to control attrition(Board Member, Interview, Suratkal, 2011).

Control is defined as an ability or authority to manage or direct something. It also includes the process of limiting, or restricting, somebody or something, or the methods used in attaining this. Thus, overall, it is the authority, ability and process to control something and/or somebody successfully. The subsidiary was now not only a center of excellence ( $\mathrm{CoE})$, but was also responsible for overall operations, with additional responsibility of strategic decision-making, including budgeting and costing. The following quote explains this:

Our Indian operations are now self-sufficient and the centers of excellences in Mumba and Bangalore are, in realistic terms, our Indian $H Q$. They have ideally minimized our overall control and are moving into being more strategic partners, solely responsible for our rural operations (Board Member, Interview, Bangalore, 2012).

Client interface and satisfaction is defined as the place, situation, or way, in which two things or people act together or affect each other, or the point of connection between things and the gratification with the way that this has been arranged or done. This is defined in the context of clients and customers. When the rural operations took off in this case study organization, the client had to communicate through HQ and the subsidiary CoE. To bypass these two levels of communication lines, and to have direct contact with the operations, the $\mathrm{CoE}$ at the subsidiary 
‘.most of the work at Suratkal did not require us to possess soft skills. Initially, we thought it was a necessity and an industry norm, but later realized it was not really required....clients visited us on few occasions and we put forward our employees that met the criteria of soft skills...that is speaking good English etc... Clients were extremely impressed with the quality of our work... (Manager, Suratkal, Interview,

2012).

Proven success of business models is defined as the achievement of business models that were planned, or attempted, and that have been tried and tested on earlier occasions, and known to work or be satisfactory. This is due to the institutional context of a region/subsidiary. These aspects became the subsidiaries' strengths over time. Business development in this case study organization saw an expansion of business and exportation of this successful RBPO model.Thus, its newer subsidiaries, with its CoEs and rural operations, were yielding greater control and, hence, dependency levels, as the previous arrangement/model of HQ control was proving to be less competitive, as explained in the following quote by a respondent:

We plan to continue with our new model where we will have centres of excellence based in cities where you can get thorough bred and high calibre people.... at the same time. $75 \%$ of our work first will be assigned to mainly rural tier 2 and tier 3 cities in the future, that's the model we are going to continue working on, as it has proven to be successful for us. In this ever evolving industry we have to continuously be on the lookou for such innovative models (Chief Manager, Interview, Bangalore, 2012). 
We discuss evidence of 'reverse dependency' presented in this study in the form of the seven themes above. First in terms of 'competition', evidence suggests that subsidiary pre-empted the move abroad by encouraging HQ to take the decision of moving to a rural location as opposed to a foreign location. In effect, this helped the subsidiary to become a 'center of excellence' (Holm and Pedersen 2000), where more strategic work, planning and budgeting took place. This, in turn, led to the HQ being more dependent upon the subsidiary given that the operations were extended and managed in rural India by the Indian subsidiary. Over time, this resulted in a shift in the HQ-subsidiary relationship from a position of 'best of both' (cell 2.2 of our model) to that of 'reverse dependence' (cell 1.3 of our model). This was evident from the move in position in 2012 as compared to 2010. This was further supported through our second theme where for the subsidiary to be 'cost effective', the decision to move its operations to a rural location in India was largely supported by HQ and the subsidiary. This, eventually, also led to a greater dependence on the subsidiary. Our third theme (skills) was also complementary to the above two themes, as to be competitive and cost effective, the numbers and level of 'high skilled' people became paramount. To cater to these competitive elements, especially in the context of quality, quantity and costs, HQ had to inadvertently adhere to the decision to move to a greater skill base (a combination of quality, quantity, lower attrition and costs) in rural India.

Over time, the overall responsibility of managing attrition (our fourth theme) became the prerogative of the subsidiary and not that of HQ. This change in the human resource practices within the MNE led to increased performance of the subsidiary (Fey and Björkman 2001), and, in terms of the relationship between the $\mathrm{HQ}$ and subsidiary, the responsibility of managing 
attrition was now that of the subsidiary. Evidence thus suggests that, over time, a situation in the case study organization was leading to the strategic development of the subsidiary through 'subsidiary initiative-taking' (Delany 2000). Moreover, such arrangements led to the subsidiary having greater 'control' (our fifth theme) over its Indian operations in comparison to the foreign $\mathrm{HQ}$, and, hence, this 'increased dependence' on the subsidiary. In essence, the 'control' and power over time had now shifted from HQ to the subsidiary. This position has been defined by Budhwar (2012) as 'country specific HQ'.

Our sixth theme further strengthens our argument, as there was evidence of direct foreign-client interface with the Indian operations, with HQ only getting involved with extremely urgent, quality and time related matters. Evidence suggests that this arrangement led to an increased satisfaction levels by the client, which, in turn, led to greater dependency levels on the subsidiary. Overall evidence from the last theme (that of the RBPO model being successful), in the context of dependence of the HQ on the subsidiaries, suggests that 'reverse dependence' is a newly emerging phenomenon.

This study synthesizes and extends the literature on headquarter-subsidiary relationship in the context of location embeddedness of subsidiaries. Through a longitudinal case study approach it suggests that the subsidiary entrepreneurship in locations has immobile locationbound advantages that may raise HQ's dependence on the subsidiary. Consequently, we propose that when the subsidiary has access to location-bound advantages, the degree of $\mathrm{HQ}$

dependence on the subsidiary is likely to increase. This proposition should be empirically tested, and its corroboration may enhance the specificity of resource dependence theory. 
We also suggest that local institutional environments (at the subsidiary level) positively contribute to MNE success. Given the changing institutional environment in India, an emerging $\quad \begin{aligned} & \text { Comment [VP6] This has now been } \\ & \text { improved and evidence provided? }\end{aligned}$ economy, the findings of this study need further testing.|| Further, the case study focuses on the knowledge intensive and service sector, an area where not much HQ-subsidiary dependency research has been conducted. Thus, further research that elaborates on dependency is recommended in this industry.

This study offers a refined model of a typology of HQ-subsidiary dependency scenarios. Comment [VP8]: We have clarfied Comment [VP9]: Yes, we agree it is over ambitio
sentence...

The 'transformation' scenario (cell 3.3) is highlighted as ideal for HQ-subsidiary relations, wherein HQ and subsidiary (with higher degree) depend upon each other. This is an ideal scenario because this brings about optimum utilization of resources with HQ and subsidiary drawing upon each other's strengths. We argue that future research is required to provide empirical evidence of 'transformation' as an evolving situation that would prevail in MNE success. Last, our research aids managers in understanding the implications of subsidiary entrepreneurship and location embeddedness. It suggests that reverse dependency may be helpful for foreign managers as this could help solve local issues, and, at the same time, increase overall organizational productivity and performance by keeping subsidiary employees' morale and engagement high. Reverse dependency can bring beneficial elements to bargaining and negotiation processes within the multinational corporation, a fact that may also encourage healthy internal subsidiary level competition. 
References

Barclay, D. W. 1991. "Interdepartmental Conflict in Organizational Buying: The Impact of Organizational Context." Journal of Marketing Research 22(2): 145-59.

Bates, K. A., and E. J. Flynn. 1995. "Innovation History and Competitive Advantage: A Resource-Based View Analysis of Manufacturing Technology Innovations.” Academy of Management Proceedings, 235-239

Bartlett, C.A., and S. Ghoshal. 1989. Managing across Borders: The Transnational Solution. London: Harvard Business School Press.

Birkinshaw, J.; N. Hood; and S. Jonsson. 1998. "Building Firm-Specific Advantages in

Multinational Corporations: The Role of Subsidiary Initiative." Strategic Management Journal 19(3): 221-242.

Birkinshaw, J.; M.Y. Brannen; and Tung, R. L. 2011. "From a Distance and Generalizable to Up Close and Grounded: Reclaiming a Place for Qualitative Methods in International Business

Research." Journal of International Business Studies 42(5): 573-581.

Budhwar, P. 2012. "Management of Human Resources in Foreign Firms Operating in India: The Role of HR in Country-Specific Headquarters." The International Journal of Human Resource Management 23 (12): 2514-253

Budhwar, P. S., and J. Bhatnagar. 2009. The Changing Face of People Management in India. London: Routledge.

Cantwell, J., and Mudambi, R. 2005. "MNE Competence-Creating Subsidiary Mandates." Strategic Management Journal 26(12): 1109-1128.

Costello, A.O., and T. G. Costello. 2009. "Aligning the Interests of Subsidiaries and Headquarters in Mult inational Corporations: Empirical Evidence." Multinational Business Review 17(4): 163-203.

Delany, E. 2000. "Strategic Development of the Multinational Subsidiary through Subsidiary Initiative-Taking." Long Range Planning 33(2): 220-244.

Dellestrand, H. 2011. "Subsidiary Embeddedness as a Determinant of Divisional Headquarter Involvement in Innovation Transfer Processes." Journal of International Managemen 17(3):229-242.

Dunning, J. H. 1994. "Re-Evaluating the Benefits of Foreign Direct Investment." Transnational corporations 3(1): 23-51. 
Fey, C. F., and I. Björkman. 2001. "The Effect of Human Resource Management Practices on MNC Subsidiary Performance in Russia." Journal of International Business Studies 32(1): 5975

Fladmoe-Lindquist, K., and S. Tallman. 2002. "Internationalization, Globalization, and Capability-Based Strategy." California Management Review 45(1): 116-135.

Ghoshal, S., and N. Nohria. 1989. "Internal Differentiation within Multinational

Corporations." Strategic Management Journal 10(4): 323-337.

Gupta, A., and V. Govindarajan. 2000. "Knowledge Flows within Multinational Corporations." Strategic Management Journal 21(4): 473-496.

Holm, U., and T. Pedersen. 2000. The Emergence and Impact of MNC Centers of Excellence. London: Macmillan.

Jaworski, B. J., and A. K. Kohli. 1993. "Market Orientation: Antecedents and Consequences." Journal of Marketing 57(2): 53-70.

King, N., and C. Horrocks 2012. Interviews in Qualitative Research. London: SAGE Publications Ltd.

King, N. 2012. Doing Template Analysis. In Qualitative Organizational Research: Core Methods and Current Challenges, eds. G. Symon and C. Cassell, 426- 450. London: Sage.

Lado, A. A., and M. C. Wilson. 1994. "Human Resource Systems and Sustained Competitive Advantage: A Competency-Based Perspective." Academy of Management Review 19(4): 699727.

Mahlendorf, M.D.; J. Rehring: U. Schaffer; and E. Wyszomirski. 2012. "Influencing Foreign Subsidiary Decisions through Headquarter Performance Measurement Systems." Management Decision 50(4): 688-717.

Mudambi, R. 2002 "Knowledge Management in Multinational Firms." Journal of International Management 8(1): 1-9.

Mudambi, R.; T. Pedersen.; and U. Andersson. 2014. "How Subsidiaries Gain Power in Multinational Corporations." Journal of World Business 49(1): 101-113.

NASSCOM. (2010). Nasscom Strategic Review. Retrieved from

http://www.nasscom.in/upload/SR10/ExecutiveSummary.pdf

Nohria, N., and S. Ghoshal. 1994. "Differentiated Fit and Shared Values: Alternatives for Managing Headquarters-Subsidiary Relations." Strategic Management Journal 15(6), 491-502. Pettigrew, A. 1990. "Longitudinal Field Research on Change: Theory and Practice."

Organization Science 1(3): 267-292.

Ramamurti, R. 2012. "What is Really Different About Emerging Market Multinationals?" Global Strategy Journal 2(1): 41-47. 
Salancik, G. R., and J. Pfeffer. 1977. "Who Gets Power - and How They Hold on to it: A

Strategic Contingency Model of Power." Organizational Dynamics 5(3): 2-21.

Schotter, A., and P.W. Beamish 2011. "Performance Effects of MNC Headquarters-Subsidiary Conflict and the Role of Boundary Spanners: The Case of Headquarter Initiative Rejection." Journal of International Management 17(3): 243-259.

Schwenk, C. 1989. "A Meta-Analysis on the Comparative Effectiveness of Devil's Advocacy and Dialectical Enquiry." Strategic Management Journal 10(3): 303-306.

Snow, D. A., and L. Anderson. 1991. "Researching the Homeless." In A case for the case study, ed. J. R. Feagin; A. M. Orum; and G. Sjoberg, 148-173. North Carolina: The University of North Carolina Press.

Teece, D. J. 1985. "Multinational Enterprise, Internal Governance, and Industrial Organization." The American Economic Review 75(2): 233-238.

Thomas, K. 1990. Conflict and Negotiation Processes in Organizations, In Handbook of Industrial and Organizational Psychology, eds. M. D. Dunnette, and L. M. Hough, 651-717. Palo Alto, CA: Consulting Psychological Press.

Williamson, O. E. 1981. "The Economics of Organization: The Transaction Cost

Approach." American Journal of Sociology 87(3): 548-577

Welch, C.; R. Piekkari; E. Plakoyiannaki; and E. Paavilainen-Mäntymäki. 2010. "Theorizing from Case Studies: Towards a Pluralist Future for International Business Research." Journal of International Business Studies 42(5): 740-762.

Yang, Q.; R. Mudambi, and K. Meyer. 2008. "Conventional and Reverse Knowledge Flows in Multinational Corporations?" Journal of Management 34(5): 882-902.

Yin, R. 2009. Case study Research: Design and Methods. London: Sage.

Xia, J. 2011. "Mutual Dependence, Partner Substitutability, and Repeated Partnership: The Survival of Cross-Border Alliances." Strategic Management Journal 32(3): 229-253. 